\title{
The use of green banana (Musa balbisiana) pulp and peel flour as an ingredient for tagliatelle pasta
}

\author{
Uso da farinha de polpa e de casca de banana verde (Musa balbisiana) como \\ ingrediente para a elaboração de massa tipo talharim
}

\author{
Vanessa Naciuk Castelo-Branco', Janaína Nogueira Guimarães², Lívia Souza 3 , Marcella Rodrigues Guedes ${ }^{4}$, \\ Patrícia Moreira Silva ${ }^{5}$, Luana Limoeiro Ferrão ${ }^{6}$, Roberta Fontanive Miyahira ${ }^{7}$, Renata Rangel Guimarães ${ }^{7}$ \\ Suzana Maria Lemos Freitas ${ }^{7}$, Marta Citelli dos Reis ${ }^{7}$, Lilia Zago ${ }^{7 *}$ \\ 1 Universidade Federal Fluminense (UFF), Faculdade de Farmácia, Departamento de Bromatologia, Niterói/RJ - Brazil \\ 2 Fundação Oswaldo Cruz (Fiocruz), Escola Nacional de Saúde Pública Sérgio Arouca, Rio de Janeiro/RJ - Brazil \\ ${ }^{3}$ Hospital Oeste D'Or, Rio de Janeiro/RJ - Brazil \\ ${ }^{4}$ Universidade do Estado do Rio de Janeiro (UERJ), Fisiopatologia Clínica e Experimental, Rio de Janeiro/RJ - Brazil \\ ${ }^{5}$ Hospital Barra D'Or, Rio de Janeiro/RJ - Brazil \\ 6 Universidade Estácio de Sá, Rio de Janeiro/RJ - Brazil \\ 7 Universidade do Estado do Rio de Janeiro (UERJ), Instituto de Nutrição, Departamento de Nutrição Básica e Experimental, Rio de Janeiro/RJ - Brazil
}

\section{*Corresponding Author}

Lilia Zago, Universidade do Estado do Rio de Janeiro (UERJ), Instituto de Nutrição, Departamento de Nutrição Básica e Experimental, Rua São Francisco Xavier, 524, 12 andar, sala 12006, Maracanã, CEP: 20550-900, Rio de Janeiro/RJ - Brazil, e-mail: lilia.zago@gmail.com

Cite as: The use of green banana (Musa balbisiana) pulp and peel flour as an ingredient for tagliatelle pasta. Braz. J. Food Technol., v. 20, e2016119, 2017.

Received: Sept. 02, 2016; Accepted: June 27, 2017

\section{Abstract}

Green banana flour shows good potential as a functional ingredient for special-purpose foods, but there are no data in the literature concerning the use of a green banana pulp and peel flour for the development of products such as pasta. The aim of the present study was to develop tagliatelle pasta substituting the wheat flour with different concentrations of a green banana mixed pulp and peel flour. The pasta formulations were prepared replacing the wheat flour by the green banana mixed pulp and peel flour in two concentrations: $15 \%$ and $30 \%$. A control formulation with wheat flour was also prepared. The green banana mixed pulp and peel flour presented higher ash, total fibre and total phenolic compound contents than traditional wheat flour. The pasta formulation with the addition of $15 \%$ green banana flour showed the highest ash content and the best sensory acceptability of all the formulations. It was concluded that it was possible to develop a tagliatelle pasta with satisfactory acceptance replacing the wheat flour by a green banana mixed pulp and peel flour.

Keywords: Functional foods; Sensory acceptance; Bioactive compounds.

\section{Resumo}

A farinha de banana verde possui grande potencial como ingrediente funcional em alimentos para fins especiais. No entanto, não há dados na literatura sobre a utilização da mistura de farinha da casca e da polpa da banana verde para o desenvolvimento de produtos, como massas. O objetivo deste trabalho foi desenvolver uma massa alimentícia tipo talharim, substituindo a farinha de trigo por uma mistura de farinha de polpa e de casca de banana verde, em diferentes concentrações. As formulações foram preparadas substituindo a farinha de trigo pela mistura de farinha de polpa e de casca de banana verde em duas concentrações: $15 \%$ e $30 \%$. Uma formulação controle com farinha de trigo foi elaborada. As farinhas de polpa e de casca de banana verde apresentaram maiores teores de cinzas, fibras totais e compostos fenólicos totais. A formulação adicionada de $15 \%$ da farinha de banana verde apresentou o maior teor de cinzas e a melhor aceitabilidade entre as formulações. Desta forma, foi possível desenvolver uma massa alimentícia tipo talharim com aceitação sensorial satisfatória.

Palavras-chave: Alimentos funcionais; Aceitação sensorial; Compostos bioativos. 


\section{Introduction}

Banana is the main fruit in international trade and one of the most consumed fruits in the world. Today, banana is the fourth most widespread fruit crop in the world being produced mainly in tropical and subtropical regions. Furthermore, banana production is an important source of income and employment for the major banana export countries such as Brazil (FAO, 2011a; COELHO JUNIOR, 2013). In 2013 Brazil produced about seven million tons of bananas (IBGE, 2013) and the average consumption of the fruit is about $31 \mathrm{~kg} /$ inhabitant/year (FAO, 2011a). The great availability of green bananas in producing regions throughout the year makes their transformation into flour of great interest, besides being an important alternative to avoid possible waste of the production (TRIBESS et al., 2009). Only in recent years has the green banana aroused interest on the consumer market, and consequently many studies are being developed to assess its technological properties as a functional ingredient, especially in the form of flour, including that produced from the peel and pulp (BEZERRA et al., 2013; SARAWONG et al., 2014; ZHANG et al., 2005).

The green banana is rich in dietary fibre, essential minerals such as potassium and magnesium, and vitamins (ALKARKHI et al., 2010; CHOO; AZIZ, 2010). In addition, the green banana is rich in antioxidants including flavonoids and vitamins $A$ and $C$, and also in resistant starch, which can present positive health effects regarding the glycemic index, cholesterol lowering and fermentation capability in the human colon. Therefore the regular consumption of green banana could provide beneficial health effects due to its high content of these nutrient and non-nutrient compounds (FAO, 2011b; LEHMANN et al., 2002).

Recently, some studies have investigated the incorporation of green banana pulp flour (GBP) in different products such as noodles (CHOO; AZIZ, 2010; SAIFULLAH et al., 2009), nuggets (KUMAR et al., 2013), cookies, cake powder mixes and breads (FASOLIN et al., 2007; AGAMA-ACEVEDO et al., 2012; JUAREZ-GARCIA et al., 2006; BORGES et al., 2010) and pasta (ZANDONADI et al., 2012; KRISHNAN; PRABHASANKAR, 2010). However, the green banana peel, which possibly presents higher antioxidant activity than the pulp, has been underutilized (ALKARKHI et al., 2010). In addition, no studies were found in the literature using green banana peel flour (GBPE) mixed with GBP in order to develop more nutritional products such as pasta.

Pasta is normally high in starch but low in dietary fibre, minerals, vitamins and antioxidants. However, its consumption has increased in the last decades due to its versatility and shelf life (KRISHNAN; PRABHASANKAR, 2010). Brazil is the third largest consumer market for pasta, and in 2015 pasta consumption in Brazil was $6.17 \mathrm{~kg} /$ per capita/year (ABIMA, 2015). Therefore, the incorporation of GBP and
GBPE could be important for the development of pasta with high nutritional and functional value. The aim of the present study was to develop nutritional pasta with satisfactory sensory acceptance by substituting wheat flour with a mixture of pulp and peel green banana flours (GBF) at two concentrations.

\section{Material and methods}

\subsection{Material}

The pasta ingredients and green bananas (Musa balbisiana) were purchased at a local supermarket in Rio de Janeiro, Brazil. The chemicals and reagents used were of analytical grade (Vetec, Rio de Janeiro, Brazil).

Preparation of green banana pulp flour (GBP) and green banana peel flour (GBPE): a total of six pounds of green banana (stage 1 of ripening: all green) was washed and immersed in a hypochlorite solution (200 ppm) for 15 minutes. The hypochlorite was removed with running water and the fruits were then manually separated into pulp and peel. The pulps and peels were cut into transverse slices of about $0.5 \mathrm{~cm}$ and into thin strips of about $1 \mathrm{~cm}$, respectively. The pulp slices and peel strips were dried in a ventilated dryer (FANEM dryer, model 330, Brazil) at $60{ }^{\circ} \mathrm{C}$ for 20 hours, and then ground in a laboratory mill (Multiuse Mill, model TE 631/2, Brazil) to produce the flours, which were stored in airtight sterile plastic packs at $4{ }^{\circ} \mathrm{C}$ until analysed. The flour yields were calculated by dividing the amount of each flour produced by the amount of fresh green banana used, and the results expressed as percentage.

\subsection{Pasta preparation}

The pastas were prepared according to the formulations presented in Table 1. Three pasta formulations were developed, replacing the wheat flour with increasing levels of GBF. The proportion of green banana pulp to green banana peel in the flour mixture was $4: 1(\mathrm{w} / \mathrm{w})$. The pasta formulations contained 0\% GBF (control), 15\% GPF and $30 \%$ GBF. For the pasta preparation all the ingredients

Table 1. Ingredients used in the control and in the substituting wheat flour + GBF tagliatelle pasta formulations.

\begin{tabular}{lccc}
\multirow{2}{*}{ Ingredients (\%) } & \multicolumn{3}{c}{ Pasta Formulations } \\
\cline { 2 - 4 } Wheat flour & Control & $\mathbf{1 5 \%}$ GBFA & $\mathbf{3 0 \%}$ GBF \\
Pulp flour & 64 & 45 & 30 \\
Peel flour & - & 12 & 24 \\
Egg & - & 3 & 6 \\
Extra virgin olive oil & 32 & 37 & 37 \\
Salt & 1 & 3 & 3 \\
\hline
\end{tabular}

A GBF: pulp and peel green banana flour mixture (80\% pulp flour; $20 \%$ peel flour); For pasta formulations with GBF it was necessary to increase the egg content in order to improve the consistency. 
were manually mixed and homogenized and then sheeted using a pasta machine (Multipast Marcato Wellness, Brazil). All the formulations were dried in a ventilated dryer at $60{ }^{\circ} \mathrm{C}$ for 2 hours before storing in sterile plastic packs at $4{ }^{\circ} \mathrm{C}$ until analysed.

\subsection{Colour measurement}

The surface colour of the green banana peel was measured in different regions of a representative sample using a digital colorimeter (Konica Minolta, CR-400) in order to obtain data to characterize the stage of ripening. The parameters $L^{*}, a^{*}$ and $b^{*}$ were evaluated. $L^{*}$ represents the luminosity on a scale varying from zero to 100 (minimum brightness = zero; maximum brightness = 100); $a^{*}$ indicates the intensity of the green and red colours (negative values = green; positive values = red); and $b^{*}$ indicates the intensity of the yellow and blue colours (negative values $=$ blue; positive values $=$ yellow). All these parameters specify the colour range and intensity of the green banana used to prepare the flour.

\subsection{Chemical composition}

The moisture, ash, crude fat, crude fibre and protein contents of the flours and tagliatelle pasta formulations were determined according to the AOAC (1995) methods. The sample moisture contents were determined by oven drying (FANEM dryer, model 315SE, Brazil) at $105{ }^{\circ} \mathrm{C}$ to constant weight (method 925.10), while ash was determined by incineration of the samples in a muffle at $550{ }^{\circ} \mathrm{C}$ to constant weight (method 923.03). Crude fat was determined using the Soxhlet method followed by evaporation to constant weight (method 920.39) and protein was analysed by the Kjeldahl method using a conversion factor of 6.25 (method 960.2). Crude fibre was determined using the non-enzymatic gravimetric method (method 044/IV) according to The Adolfo Lutz Institute (IAL, 2008), and carbohydrate was determined by difference. All the analyses were carried out in duplicate and the results expressed as $\mathrm{g} / 100 \mathrm{~g}$ of sample. The results obtained for the chemical compositions of the GBP and GBPE were compared with the values reported for wheat flour in the Brazilian Table of Food Composition (UNICAMP, 2011).

\subsection{Total phenolic compounds}

The total phenolic compounds were determined in the methanol/water (50\% v/v) extracts using the Folin-Ciocalteau assay according to Aziz et al. (2011), as follows: $0.1 \mathrm{~mL}$ of methanolic extract $(0.05 \mathrm{mg} / \mathrm{mL})$ was mixed with $0.5 \mathrm{~mL}$ of Folin-Ciocalteau reagent, followed by the addition of $6 \mathrm{~mL}$ of distilled water and $2 \mathrm{~mL}$ of sodium carbonate $(15 \% \mathrm{w} / \mathrm{v})$. The solutions were mixed and allowed to stand for 1 hour at room temperature. The absorbance was measured at $765 \mathrm{~nm}$, using a UV-VIS spectrophotometer
(Micronal, model B442, Brazil). A calibration curve was prepared using a standard solution of gallic acid, and the results expressed as milligrams of gallic acid equivalents (mg GAE) / $100 \mathrm{~g}$ of samples.

\subsection{Microbiological analysis}

The microbiological analyses of the formulations included the determination of the most probable number (MPN) of coliform organisms at $35^{\circ} \mathrm{C}$ and of thermo-tolerant coliforms, the detection of Salmonella spp., and the enumeration of Bacillus cereus and coagulase-positive staphylococci according to APHA (2001). The results were compared with the Brazilian Legislation (BRASIL, 2001).

\subsection{Sensory evaluation}

Forty non-trained judges from the Rio de Janeiro State University were recruited to carry out the sensory analysis of the cooked pasta using a 9-point hedonic scale, where 9 = extremely desirable and 1 = extremely undesirable. The number of judges required for acceptance tests is sixty, hence the results presented are indicative, but important enough to be reported and discussed. All the pastas were cut into uniform pieces, cooked in boiled water and seasoned with garlic and olive oil to be served to the judges. Water at room temperature was provided to cleanse the palate between samples. The sensory attributes evaluated were appearance, texture and flavour. The results were expressed as the mean score and the acceptance index (AI) was calculated as follows: $\mathrm{Al}(\%)=A^{*} 100 / B$, where $A$ was the mean score obtained for each formulation and $B$ was the maximum score obtained. The pasta formulations with an Al higher than $70 \%$ were considered to be well accepted (QUEIROZ; TREPTOW, 2006).

\subsection{Ethics}

The Project complied with all ethical principles, was consistent with the assumptions of the Resolution of the National Health Council 196/96 and approved by the Ethics Committee of the Pedro Ernesto University Hospital - HUPE (CAAE - 04170612.8.0000.5259).

\subsection{Statistical analysis}

All the results were presented as the mean \pm standard deviation of duplicates. The analysis of variance (ANOVA) followed by Tukey's post-hoc test was used to compare the chemical composition of the pasta formulations, and the Student's $t$ test was used to compare the chemical compositions of the pulp and peel flours. $P$ values $<0.05$ were considered statistically significant. All the data were analysed using the GraphPad Prism v. 4.00 for Windows, GraphPad Software (California, USA). 


\section{Results and discussion}

\subsection{Colour characterization of the green bananas}

The intensity and range of the peel surface colour were measured in order to better describe the stage of ripening of the green bananas used in the present study. No colour change of the peels as a result of ripening was observed. The prevalence of greenish tones is to be expected as compared to reddish and yellowish tones, corresponding to a decrease in the values for $a^{\star}$ and $b^{*}$ (Table 2). Accordingly, the colorimetric coordinates observed here were compatible with the all green stage of ripening as the green bananas used in the present study were classified.

\subsection{Chemical characterization of the GBP and GBPE}

The GBP and GBPE produced in this study were creamy pale-yellow and brownish in colour, respectively. The flour yield was $17.8 \%$ for GBP and $3.8 \%$ for GBPE. The green banana pulp yields obtained in a drying oven in experiments carried out by Nimsung et al. (2007), Bertolini et al. (2010) and Santos et al. (2010), ranged from 29.8\% to $56 \%$. The green banana flour yield can be influenced by factors such as different cultivars and techniques and the dehydration conditions (SILVA et al., 2015). These factors may explain the yields obtained in the present experiments, since the chemical composition of the variety studied in this work, as well as the dehydration conditions were different from the above mentioned experiments.

The chemical compositions of the GBP and GBPE are presented in Table 3. The moisture, ash, protein, fat, carbohydrate and fibre contents of the GBP and GBPE were significantly different. GBP presented the highest moisture, ash and carbohydrate contents while the GBPE presented the highest protein, fat and fibre contents. Moreover, the GBP and GBPE presented higher ash and fibre contents than the wheat flour. On the other hand, the GBP and GBPE presented lower protein contents than the wheat flour. In this respect, the addition of both the green banana flours as an ingredient in food products might reduce the nutritional value with respect to the protein content. However, they might add nutritional value to the product with respect to minerals and fibre, considering the higher values of these components when compared with the wheat flour (Table 3).

In addition, green banana flour is rich in resistant starch, widely recognized in the literature as having important physiological implications with respect to human health, such as beneficial bacterial growth in the colon, post-prandial glycemic control and cholesterol lowering. Therefore, green banana flour might also contribute to increasing the consumption of resistant starch in the human diet (CHOO; AZIZ, 2010; LEHMANN et al., 2002; MENEZES et al., 2011; TRIBESS et al., 2009).

The results obtained for the moisture, ash, protein, fat and carbohydrate contents of GBP were in accordance with the results of Borges et al. (2009) and Krishnan and Prabhasankar (2010). However, Borges et al. (2009) observed a smaller content of crude fibre $(1.01 \pm 0.02 \mathrm{~g} / 100 \mathrm{~g})$ than observed in the present study (Table 3 ). This variation might be attributed mainly to differences in the agricultural practices, stage of maturation and banana cultivar investigated (EMAGA et al., 2007).

GBPE presented a crude fibre content that was twice as high as that of the GBP. Also, both, GBP and GBPE presented higher fibre contents than the wheat flour

Table 2. Colour description of the green banana peel based on the colorimetric coordinates.

\begin{tabular}{ccccc}
\hline Value & minimum & maximum & mean & Standard deviation \\
\hline$L^{*}$ value & 44.45 & 54.03 & 49.74 & 3.12 \\
$a^{*}$ value & -21.46 & -18.16 & -20.31 & 1.08 \\
$b^{*}$ value & 32.34 & 38.43 & 35.13 & 1.84 \\
\hline
\end{tabular}

$\mathrm{L}^{*}$ indicates luminosity; $\mathrm{a}^{*}$ indicates the intensity of the green and red colours; $b^{*}$ indicates the intensity of the yellow and blue colours.

Table 3. Comparison of the chemical compositions of the green banana pulp, green banana peel and wheat flours.

\begin{tabular}{|c|c|c|c|}
\hline \multirow{2}{*}{ Chemical composition (g/ 100g) } & \multicolumn{3}{|c|}{ Flours } \\
\hline & GBP & GBPE & Wheat $^{\mathrm{B}}$ \\
\hline Moisture & $3.17 \pm 0.13^{a}$ & $2.21 \pm 0.11^{b}$ & 13.0 \\
\hline Ash & $2.54 \pm 0.12^{a}$ & $2.33 \pm 0.01^{b}$ & 0.8 \\
\hline Protein & $4.60 \pm 1.23^{b}$ & $7.52 \pm 1.13^{a}$ & 9.8 \\
\hline Fat & $0.48 \pm 0.02^{b}$ & $9.04 \pm 0.42^{a}$ & 1.4 \\
\hline Carbohydrate $^{A}$ & $84.4 \pm 1.26^{a}$ & $70.0 \pm 1.67^{b}$ & 72.7 \\
\hline Fibre & $4.77 \pm 0.01^{b}$ & $8.89 \pm 0.01^{a}$ & 2.3 \\
\hline Total phenolic compounds (mg GAE /100g) & $32.9 \pm 0.64^{b}$ & $40.3 \pm 0.59^{a}$ & ND \\
\hline
\end{tabular}

GBP: green banana pulp; GBPE: green banana peel. All values are means \pm standard deviation of duplicates. Different superscript letters in the same row indicate significant differences $(p<0.05)$; ${ }^{A}$ Calculated by difference; ${ }^{B}$ Composition values according to the Brazilian Table of Food Composition (UNICAMP, 2011); ND = not detected; GAE: gallic acid equivalents. 
(Table 3). Banana peel is reported to be rich in dietary fibre, mainly hemicelluloses, which might constitute $20 \%$ of the peel (ALKARKHI et al., 2010). In this respect, it is possible that the addition of GBP and GBPE to new pasta formulations could provide higher fibre content for this product. Thus green banana flour obtained from the pulp and especially from the peel could be used as a good alternative to increase the fibre content of the human diet.

\subsection{Total phenolic compounds}

The amounts of total phenolic compounds found in the GBP and GBPE flours can be seen in Table 3. The GBPE presented more total phenolic compounds than the GBP. However, the total phenolic compounds of the wheat flour could not be determined, probably because the amount present was below the quantification threshold of the method used.

Menezes et al. (2011) investigated the total phenolic compound content of the GBP from the banana variety Cavendish, known as nanicão in Brazil, and observed a content of $50.65 \pm 0.08 \mathrm{mg} \mathrm{GAE} / 100 \mathrm{~g}$ dry matter. The GBP produced in the present study was elaborated from the variety Balbisiana (prata) and presented lower total phenolic compound contents than those observed by Menezes et al. (2011). This difference might be attributed to the varieties of banana used in both studies and also to the phenolic extraction method used by the authors, where the sample was subjected to extraction by an ultrasound-assisted method. The phenolic contents of fruits, even when extracted from the same species, depend on a number of intrinsic and extrinsic factors, such as cultivars, agricultural practices and the phenolic extraction methods used (BALASUNDRAM et al., 2006).

Nevertheless, the GBP and GBPE produced in the present study are potential alternatives to increase the amount of phenolic compounds in the diet when replacing wheat flour, which is widely used and showed no detectable amounts of phenolic compounds.

It is very important to emphasize that, even if pesticides are used correctly and in compliance with current legislation, the food can present residues. This fact should be taken into account when using whole food, as these residues may be deposited mainly on the outer layers of the foods. Thus strict care should be taken with proper washing prior to use. In addition, the use of bananas obtained from producers where good agricultural practices are guaranteed, should always be considered (CANTARUTTI et al., 2008).

\subsection{Chemical composition of the pasta samples}

Table 4 shows the mean values obtained for the chemical compositions of the control, and the 15\% and $30 \%$ GBF tagliatelle pasta formulations. The ash contents of the pasta formulations increased in proportion to the addition of GBF, such that the formulation with 30\% GBF presented twice the ash content of the control formulation. This was due to the higher ash contents of the GBP and GBPE, corresponding to the higher mineral content of the green banana, especially the potassium and magnesium contents (ALKARKHI et al., 2011; UNICAMP, 2011). As in the present study, Choo and Aziz (2010) and Krishnan and Prabhasankar (2010) also observed increased ash contents when adding different green banana pulp flour concentrations to noodles and pasta, respectively.

There were no significant differences between the formulations with respect to the protein, moisture and carbohydrate contents. Krishnan and Prabhasankar (2010) observed a significant decrease in protein content with the increase in substitution level by GBF in pasta. Although a reduction in protein content was expected when substituting wheat flour with GBF in the tagliatelle pasta formulations, this was not observed, possibly due to the addition of an egg to these formulations.

\subsection{Microbiological analysis}

Prior to the sensory evaluations, all the pasta formulations were submitted to a microbiological analysis, and showed values below those recommended by the Brazilian Legislation (BRASIL, 2001) as shown in Table 5.

\subsection{Sensory evaluation}

It is important to highlight that the results obtained in the sensory analysis are indicative, since the number of judges (forty) was less than the required number (sixty), but in spite of this, the findings were important and should be described and discussed. The mean scores and Al values

Table 4. Chemical compositions $(\mathrm{g} / 100 \mathrm{~g})$ of the tagliatelle pasta formulations.

\begin{tabular}{ccccccc}
$\begin{array}{c}\text { Tagliatelle } \\
\text { Samples }\end{array}$ & Moisture & Ash & Protein & Fat & Carbohydrate $^{\mathrm{B}}$ & Total fibre $^{\mathrm{c}}$ \\
Control & $15.7 \pm 0.15^{\mathrm{a}}$ & $1.51 \pm 0.00^{\mathrm{c}}$ & $13.4 \pm 0.00^{\mathrm{a}}$ & $8.48 \pm 0.03^{\mathrm{b}}$ & $59.4 \pm 0.19^{\mathrm{a}}$ & 1.47 \\
$15 \% \mathrm{GBF}$ & $15.6 \pm 0.15^{\mathrm{a}}$ & $2.23 \pm 0.03^{\mathrm{b}}$ & $12.2 \pm 0.08^{\mathrm{a}}$ & $8.65 \pm 0.02^{\mathrm{b}}$ & $59.4 \pm 0.22^{\mathrm{a}}$ & 1.86 \\
$30 \% \mathrm{GBF}$ & $16.0 \pm 0.32^{\mathrm{a}}$ & $2.96 \pm 0.02^{\mathrm{a}}$ & $11.9 \pm 0.41^{\mathrm{a}}$ & $9.26 \pm 0.33^{\mathrm{a}}$ & $57.4 \pm 0.44^{\mathrm{a}}$ & 2.36 \\
\hline
\end{tabular}

All values are means \pm standard deviation of duplicates. Different superscript letters in the same column indicate significant differences ( $p<0.05$ ); A GBF: mixture of green banana pulp and peel flours; ${ }^{B}$ Calculated by difference; ${ }^{C}$ Calculated from the total fibre content in the flour samples. 
The use of green banana (Musa balbisiana) pulp and peel flour as an ingredient for tagliatelle pasta

Castelo-Branco, V. N. et al.

for the sensory attributes of appearance, texture and flavour for all the pasta formulations are presented in Table 6.

Regarding the mean scores, a statistical difference amongst the three formulations studied can be observed for the attribute of appearance, the highest mean score being awarded to the control $(7.7 \pm 1.03)$ and the lowest to the $15 \% \operatorname{GBF}(4.5 \pm 1.90)$. For texture, a significant difference was observed between the GBF groups, 30\% GBF being awarded the highest mean (7.4 \pm 1.14$)$. Regarding flavour, the $30 \%$ GBF formulation presented the highest mean $(7.4 \pm 1.69)$, being significantly different from the control which had a mean of $6.4 \pm 1.61$. Regarding the attributes evaluated, it can be said that in replacing the wheat flour with GBF, it was possible to maintain some similar technological properties of the traditional pasta. The lower mean score (4.5) awarded to the appearance of the $15 \%$ GBF pastas may have been associated with the colour of the pastas. Although the 30\% GBF formulation was even darker, which could have been a negative aspect it received a higher mean score. This fact could be explained by consumer expectation. Since the 30\% GBF pasta was the product with the highest nutritional value, including the highest fibre content, it is possible that the consumers expected a darker colour for pasta with increased fibre content, establishing a positive association between darker colour and higher fibre contents.

In general there were significant differences between the $15 \%$ and $30 \%$ GBF pastas for all the attributes evaluated, and hence the concentration of GBF added to the pasta formulations probably influenced the acceptance of the GBF-substituted tagliatelle pastas. Moreover, the 30\% GBF pasta formulation presented the highest mean score for the three attributes investigated.

Considering $\mathrm{Al}$ (Table 6), both the $15 \%$ and $30 \%$ GBF tagliatelle formulations achieved scores above 80\% for flavour, demonstrating good acceptability for this attribute. Besides, the 30\% GBF tagliatelle showed the highest AI for appearance of the two GBF-substituted tagliatelle pasta formulations investigated. Therefore, taking into account the mean scores and the Al for the texture and flavour attributes, the 30\% GBF tagliatelle was more accepted. Although the Al values were below $70 \%$ for appearance, the $30 \%$ GBF had a higher Al than the 15\% GBF for this attribute, demonstrating that the $30 \%$ GBF was the better substitution level for the GBF pasta formulation.

Krishnan and Prabhasankar (2010) replaced wheat flour with GBP in pasta formulations at concentrations varying from $20 \%$ to $30 \%$. These authors only observed moderately acceptable cooking and sensory qualities for the $20 \%$ substituting pasta formulation. Moreover, Choo and Aziz (2010) only observed good overall acceptability for the 30\% GBP-substituted noodle formulation. The present study was the first one to develop tagliatelle pasta formulations replacing wheat flour with up to $30 \%$ of GBF, and obtaining good acceptability. The present authors also tried to develop a formulation with $100 \%$ GBF but the data were not published in the present study since this pasta formulation did not achieve satisfactory technological properties. In addition, to the authors' knowledge, this was the first time green banana peel flour was used to increase the nutritional value of tagliatelle pasta formulations.

Table 5. Bacterial counts in the different pasta formulations.

\begin{tabular}{|c|c|c|c|c|}
\hline \multirow{2}{*}{ Microorganisms } & \multicolumn{3}{|c|}{ Formulations } & \multirow{2}{*}{$\begin{array}{l}\text { Brazilian } \\
\text { Legislation }\end{array}$} \\
\hline & Control & GBF $15 \%$ & GBF $30 \%$ & \\
\hline Coliforms at $35^{\circ} \mathrm{C}\left(\mathrm{MPN} \mathrm{g}^{-1}\right)$ & $<3.0$ & $<3.0$ & $<3.0$ & - \\
\hline Thermotolerant coliforms (MPN g ${ }^{-1}$ ) & $<3.0$ & $<3.0$ & $<3.0$ & $10^{2}$ \\
\hline $\begin{array}{l}\text { Coagulase positive staphylococci } \\
\left.(\mathrm{CFU} \mathrm{g})^{-1}\right)^{A}\end{array}$ & $<1 \times 10^{2}$ & $<1 \times 10^{2}$ & $<1 \times 10^{2}$ & $5 \times 10^{3}$ \\
\hline Salmonella spp. & absence in $25 \mathrm{~g}$ & absence in $25 \mathrm{~g}$ & absence in $25 \mathrm{~g}$ & absence in $25 \mathrm{~g}$ \\
\hline Bacillus cereus (CFU g ${ }^{-1}$ ) & $<1 \times 10^{2}$ & $<1 \times 10^{2}$ & $<1 \times 10^{2}$ & $5 \times 10^{3}$ \\
\hline
\end{tabular}

${ }^{\mathrm{A}} \mathrm{CFU}$ : colony forming unit.

Table 6. Mean scores and acceptability indexes of the different tagliatelle pasta formulations.

\begin{tabular}{|c|c|c|c|c|c|c|}
\hline \multicolumn{7}{|c|}{ Sensory Attributes } \\
\hline \multirow{2}{*}{$\begin{array}{c}\text { Pasta } \\
\text { formulations }\end{array}$} & \multicolumn{3}{|c|}{ Mean Score A $^{\text {A }}$} & \multicolumn{3}{|c|}{ Acceptability Index $(\%)^{B}$} \\
\hline & Appearance & Texture & Flavour & Appearance & Texture & Flavour \\
\hline Control & $7.7 \pm 1.03^{a}$ & $7.2 \pm 1.37^{a, b}$ & $6.4 \pm 1.61^{b}$ & 85.0 & 80.3 & 70.8 \\
\hline $15 \% \mathrm{GBF}^{\mathrm{C}}$ & $4.5 \pm 1.90^{\circ}$ & $6.6 \pm 1.31^{b}$ & $7.3 \pm 0.91^{a, b}$ & 50.2 & 73.8 & 81.4 \\
\hline $30 \% \mathrm{GBF}$ & $6.0 \pm 1.89^{b}$ & $7.4 \pm 1.14^{\mathrm{a}}$ & $7.4 \pm 1.69^{a}$ & 66.1 & 82.6 & 81.7 \\
\hline
\end{tabular}

${ }^{A}$ All values are means \pm standard deviation. Different superscript letter in the same column indicate significant differences $(p<0.05) ;{ }^{B}$ Acceptance Index (\%): mean score x100/ maximum score; ${ }^{\mathrm{C}} \mathrm{GBF}$ : pulp and peel green banana mixture flour. 
The use of green banana (Musa balbisiana) pulp and peel flour as an ingredient for tagliatelle pasta

Castelo-Branco, V. N. et al.

\section{Conclusions}

The present study developed different pasta formulations substituting wheat flour by GBF at two concentrations: $15 \%$ and $30 \%$. The findings suggested that the replacement of wheat flour by $50 \%$ of GBF $(30 \%$ of GBF in the complete formulation) provided pasta with good sensory acceptance and could represent an alternative functional ingredient for pasta.

\section{References}

AGAMA-ACEVEDO, E.; ISLAS-HERNÁNDEZ, J. J.; PACHECOVARGAS, G.; OSORIO-DÍAZ, P.; BELLO-PÉREZ, L. A. Starch digestibility and glycemic index of cookies partially substituted with unripe banana flour. Lebensmittel-Wissenschaft + Technologie, v. 46, n. 1, p. 177-182, 2012. http://dx.doi. org/10.1016/j.Iwt.2011.10.010.

ALKARKHI, A. F. M.; RAMLI, S. B.; YONG, Y. S.; EASA, A. M. Physicochemical properties of banana peel flour as influenced by variety and stage of ripeness: multivariate statistical analysis. Asian Journal of Food and Agro-Industry, v. 3, n. 3, p. 349-362, 2010.

ALKARKHI, A. F. M.; RAMLI, S. B.; YONG, Y. S.; EASA, A. M. Comparing physicochemical properties of banana pulp and peel flours prepared from green and ripe fruits. Food Chemistry, v. 129, n. 2, p. 312-318, 2011. PMid:25212137. http://dx.doi. org/10.1016/j.foodchem.2011.04.060.

AMERICAN PUBLIC HEALTH ASSOCIATION - APHA. Compendium of methods for the microbiological examination of foods. 4th ed. Washington: APHA, 2001

ASSOCIAÇÃO BRASILEIRA DE INDÚSTRIAS DE MASSAS ALIMENTÍCIAS - ABIMA. Estatísticas. São Paulo: ABIMA, 2015. Available at: <http://www.abima.com.br/>. Accessed on: 20 dec. 2016.

ASSOCIATION OF OFFICIAL ANALYTICAL CHEMISTRY $A O A C$. Official methods of analysis. 16th ed. Arlington: AOAC International, 1995.

AZIZ, N. A. A.; HO, L.-H.; AZAHARI, B.; BHAT, R.; CHENG, L.-H.; IBRAHIM, M. N. M. Chemical and functional properties of the native banana (Musa acuminata $\mathrm{x}$ balbisiana Colla $\mathrm{cv}$. Awak) pseudo-stem and pseudo-stem tender core flours. Food Chemistry, v. 128, n. 3, p. 748-753, 2011. http://dx.doi. org/10.1016/j.foodchem.2011.03.100.

BALASUNDRAM, N.; SUNDRAM, K.; SAMMAN, S. Phenolic compounds in plants and agri-industrial by-products: antioxidant activity, occurrence, and potential uses. Food Chemistry, v. 99, n. 1, p. 191-203, 2006. http://dx.doi.org/10.1016/j. foodchem.2005.07.042.

BERTOLINI, A. C.; BELLO-PÉREZ, L. A.; MÉNDEZ-MONTEALVO, G.; ALMEIDA, C. A. S.; LAJOLO, F. Rheological and functional properties of flours from banana pulp and peel. Stärke, v. 62, n. 6, p. 277-284, 2010. http://dx.doi.org/10.1002/star.200900216.

BEZERRA, C. V.; AMANTE, E. R.; OLIVEIRA, D. C.; RODRIGUES, A. M. C.; SILVA, L. H. M. Green banana (Musa cavendishii) flour obtained in spouted bed: effect of drying on physicochemical, functional and morphological characteristics of the starch. Industrial Crops and Products, v. 41, p. 241-249, 2013. http:// dx.doi.org/10.1016/j.indcrop.2012.04.035.

BORGES, A. M.; PEREIRA, J.; LUCENA, E. M. P. Caracterização da farinha de banana verde. Ciência e Tecnologia de Alimentos, v. 29, n. 2, p. 333-339, 2009. http://dx.doi.org/10.1590/S010120612009000200015.

BORGES, A. M.; PEREIRA, J.; SILVA JÚNIOR, A. S.; LUCENA, E. M. P.; SALES, J. C. Estabilidade da pré-mistura de bolo com 60\% de farinha de banana verde. Ciência e Agrotecnologia, v. 34, n. 1, p. 173-181, 2010. http://dx.doi.org/10.1590/S141370542010000100022.

BRASIL. Ministério da Saúde. Agência Nacional de vigilância Sanitária. Resolução RDC n 12, de 2 de janeiro de 2001. Aprova Regulamento Técnico sobre os padrões microbiológicos para alimentos. Diário Oficial [da] República Federativa do Brasil, Brasília, DF, 10 jan. 2001.

CANTARUTTI, T. F. P.; ARAÚJO, S. L.; ROSSI, S. C.; DALSENTER, P. R. Resíduos de pesticidas em alimentos. Pesticidas: Revista de Ecotoxicologia e Meio Ambiente, v. 18, p. 9-16, 2008.

CHOO, C. H.; AZIZ, N. A. Effects of banana flour and -glucan on the nutritional and sensory evaluation of noodles. Food Chemistry, v. 119, n. 1, p. 34-40, 2010. http://dx.doi.org/10.1016/j. foodchem.2009.05.004.

COELHO JUNIOR, L. M. C. Concentração regional do valor de produção da banana do Paraná, Brasil (1995 a 2010). Ciência Rural, v. 43, n. 12, p. 2304-2310, 2013. http://dx.doi.org/10.1590/ S0103-84782013005000137.

EMAGA, T. H.; ANDRIANAIVO, R. H.; WATHELET, B.; TCHANGO, J. T.; PAQUOT, M. Effects of the stage of maturation and varieties on the chemical composition of banana and plantain peels. Food Chemistry, v. 103, n. 2, p. 590-600, 2007. http://dx.doi. org/10.1016/j.foodchem.2006.09.006.

FASOLIN, L. H.; ALMEIDA, G. C.; CASTANHO, P. S.; NETTOOLIVEIRA, E. R. Biscoitos produzidos com farinha de banana verde: avaliações química, física e sensorial. Ciência e Tecnologia de Alimentos, v. 27, n. 3, p. 524-529, 2007. http:// dx.doi.org/10.1590/S0101-20612007000300016.

FOOD AND AGRICULTURE ORGANIZATION - FAO. Food balance sheets. Rome: FAO, 2011a. Available at: <http://faostat.fao. org/616/desktopdefault.aspx?PagelD=616\#ancor $>$. Accessed: 10 dez. 2011.

FOOD AND AGRICULTURE ORGANIZATION - FAO. Consumo. Rome: FAO, 2011b. Available at: <http://faostat.fao.org/site/609/ 
The use of green banana (Musa balbisiana) pulp and peel flour as an ingredient for tagliatelle pasta

Castelo-Branco, V. N. et al.

DesktopDefault.aspx?PagelD=609\#ancor>. Accessed on: 20 apr. 2016.

INSTITUTO ADOLFO LUTZ - IAL. Métodos fisico-químicos para análise de alimentos. São Paulo: IAL, 2008.

INSTITUTO BRASILEIRO DE GEOGRAFIA E ESTATÍTICA - IBGE. Levantamento sistemático da produção agrícola: pesquisa mensal de previsão e acompanhamento das safras agrícolas no ano civil. Rio de Janeiro: IBGE, 2013. Available at: <http:// www.ibge. gov.br>. Accessed on: 20 apr. 2016.

JUAREZ-GARCIA, E.; AGAMA-ACEVEDO, E.; SÁYAGO-AYERDI, S. G.; RODRÍGUEZ-AMBRIZ, S. L.; BELLO-PÉREZ, L. A. Composition, digestibility and application in bread making of banana flour. Plant Foods for Human Nutrition, v. 61, n. 3, p. 131-137, 2006. PMid:17048100. http://dx.doi.org/10.1007/s11130-006-0020-x.

KRISHNAN, M.; PRABHASANKAR, P. Studies on pasting, microstructure, sensory, and nutritional profile of pasta influenced by sprouted finger millet (Eleucina coracana) and green banana (Musa paradisiaca) flours. Journal of Texture Studies, $v$. 41, n. 6, p. 825-841, 2010. http://dx.doi.org/10.1111/j.17454603.2010.00257.x.

KUMAR, V.; BISWAS, A. K.; SAHOO, J.; CHATLI, M. K.; SIVAKUMAR, S. Quality and storability of chicken nuggets formulated with green banana and soybean hulls flours. Journal of Food Science and Technology, v. 50, n. 6, p. 1058-1068, 2013. http://dx.doi. org/10.1007/s13197-011-0442-9. PMid:24426017.

LEHMANN, U.; JACOBASCH, G.; SCHMIEDL, D. Characterization of resistant starch type III from banana (Musa acuminata). Journal of Agricultural and Food Chemistry, v. 50, n. 18, p. 5236-5240, 2002. PMid:12188636. http://dx.doi.org/10.1021/jf0203390.

MENEZES, E. W.; TADINI, C. C.; TRIBESS, T. B.; ZULETA, A.; BINAGHI, J.; PAK, N.; VERA, G.; DAN, M. C. T.; BERTOLINI, A. C.; CORDENUNSI, B. R.; LAJOLO, F. M. Chemical composition and nutritional value of unripe banana flour (Musa acuminata, var. Nanicão). Plant Foods for Human Nutrition, v. 66, n. 3, p. 231-237, 2011. PMid:21732181. http://dx.doi.org/10.1007/ s11130-011-0238-0.

NIMSUNG, P.; THONGNGAM, M.; NAIVIKUL, O. Compositions, morphological and thermal properties of green banana flour and starch. Kasetsart Journal, v. 41, p. 324-330, 2007.
QUEIROZ, M. I.; TREPTOW, R. O. Análise sensorial para avaliação da qualidade dos alimentos. Rio Grande: Editora da FURG, 2006. 266 p.

SAIFULLAH, R.; ABBAS, F. M. A.; YEOH, S.-Y.; AZHAR, M. E. Utilization of green banana flour as a functional ingredient in yellow noodle. International Food Research Journal, v. 16, n. 3, p. 373-379, 2009.

SANTOS, J. C.; SILVA, G. F.; SANTOS, J. A. B.; OLIVEIRA-JUNIOR, A. M. Processamento e avaliação da estabilidade da farinha de banana verde. Exacta, v. 8, n. 2, p. 219-224, 2010.

SARAWONG, C.; SCHOENLECHNER, R.; SEKIGUCHI, K.; BERGHOFER, E.; NG, P. K. Effect of extrusion cooking on the physicochemical properties, resistant starch, phenolic content and antioxidant capacities of green banana flour. Food Chemistry, v. 143, p. 33-39, 2014. PMid:24054209. http://dx.doi.org/10.1016/j. foodchem.2013.07.081.

SILVA, A. A.; BARBOSA-JUNIOR, J. L.; BARBOSA, M. I. M. J. Farinha de banana verde como ingrediente funcional em produtos alimentícios. Ciência Rural, v. 45, n. 12, p. 2252-2258, 2015. http://dx.doi.org/10.1590/0103-8478cr20140332.

TRIBESS, T. B.; HERNÁNDEZ-URIBE, J. P.; MÉNDEZ-MONTEALVO, M. G. C.; MENEZES, E. W.; BELLO-PEREZ, L. A.; TADINI, C. C. Thermal properties and resistant starch content of green banana flour (Musa cavendishii) produced at different drying conditions. Food Science and Technology, v. 42, n. 5, p. 1022-1025, 2009. UNIVERSIDADE ESTADUAL DE CAMPINAS - UNICAMP. TACO: tabela brasileira de composição de alimentos. Campinas: NEPAUNICAMP, 2011. 161 p.

ZANDONADI, R. P.; BOTELHO, R. B.; GANDOLFI, L.; GINANI, J. S.; MONTENEGRO, F. M.; PRATESI, R. Green banana pasta: an alternative for gluten-free diets. Journal of the Academy of Nutrition and Dietetics, v. 112, n. 7, p. 1068-1072, 2012. PMid:22889636. http://dx.doi.org/10.1016/j.jand.2012.04.002.

ZHANG, P.; WHISTLER, R. L.; BEMILLER, J. N.; HAMAKER, B. R. Resistant banana starch: production, physicochemical properties, and digestibility: a review. Carbohydrate Polymers, v. 59, n. 4, p. 443-458, 2005. http://dx.doi.org/10.1016/j.carbpol.2004.10.014. 